\title{
FORMULASI GEL EKSTRAK ETANOL KULIT BUAH MANGGIS (Garcinia mangostana L.) DENGAN VARIASI GELLING AGENT SEBAGAI SEDIAAN LUKA BAKAR \\ FORMULATION GEL ETHANOLIC EXTRACT OF PERICARP MANGOSTEEN (Garcinia mangostana L.) WITH VARIATION OF GELLING AGENTAS WOUND HEALING DOSAGE FORM
}

\author{
Lena Maulina, Nining Sugihartini \\ Fakultas Farmasi Universitas Ahmad Dahlan Yogyakarta \\ Jl. Prof. Dr. Soepomo, Janturan Yogyakarta Telp. (0274) 379418 \\ Email:nining.sugihartini@pharm.uad.ac.id
}

\begin{abstract}
ABSTRAK
Kulit buah manggis telah terbukti memiliki efek anti inflamasi dan mempercepat proliferasi fibroblas yang berhubungan dengan efek menyembuhkan luka bakar. Oleh karena itu perlu diformulasikan dalam bentuk sediaan gel untuk mempermudah dalam penggunaannya. Formulasi gel membutuhkan gelling agent agar menghasilkan gel yang baik. Penelitian ini bertujuan untuk mengetahui jenis gelling agent yang akan memberikan sifat fisik gel dan aktivitas mengobati luka bakar yang paling baik. Terdapat tiga formula gel yang dirancang dengan perbedaan jenis gelling agent yaitu : FI (gelling agent karbopol); FII (gelling agent CMC Na); FIII (gelling agent tragakan). Sediaan gel yang diperoleh diuji organoleptis, homogenitas, $\mathrm{pH}$, daya sebar, daya lekat, konsistensi dan efek menyembuhkan luka bakar. Data yang diperoleh kemudian dianalisis dengan menggunakan statistik SPSS versi 16 dengan Kolmogorov-smirnov dan dilanjutkan ANOVA satu jalan atau Kruskal-Wallis, dengan taraf kepercayaan $95 \%$. Hasil penelitian menunjukkan bahwa semua formula tercampur homogen. Formula I memilki $\mathrm{pH}$ 3,5 sedangkan formula II dan III memiliki $\mathrm{pH} 5$ $(\mathrm{p}<0,05)$. Daya sebar yang paling luas diberikan oleh formula III $(\mathrm{p}<0,05)$ dan daya lekat yang paling lama diberikan oleh formula II $(\mathrm{p}<0,05)$. Daya penyembuhan luka bakar terbaik oleh formula I ( $>0,05)$. Berdasarkan hasil tersebut menunjukan bahwa jenis gelling agent dapat mempengaruhi sifat fisik gel dan aktivitas dalam mengobati luka bakar. Jenis gelling agent yang menunjukkan sifat fisik yang paling baik adalah $\mathrm{CMC} \mathrm{Na}$.
\end{abstract}

Kata kunci: kulit buah manggis, gel, gelling agent, sifat fisik gel, luka bakar.

\section{ABSTRACT}

Pericarp of mangosteen is waste that has been shown have efficacy as an anti-inflammatory and accelerate the proliferation of fibroblasts. Therefore it need to be formulated in the form of gel to make easy in the use of preparation. It is needed an appropriate gelling agent to produce the good character of gel. This research aimed to know the type of the gelling agent who has the physical properties gel and the activity of the best treat burns. There are three gel formula designed with various type of the gelling agent i.e. FI (the gelling agent carbopol); FII (the gelling agent CMC na); FIII (the gelling agent tragacanth). The obtained gels were tested organoleptic, of homogeneity, $\mathrm{pH}$, spreadibility, adhesivity, consistency and the effect of healing burns in nine groups. The collected data were analyzed statistically using SPSS version 16 with kolmogorov-smirnov and continued one way ANOVA or Kruskal-Wallis, with level of trust $95 \%$. The results show that all formula mixed homogeneous gel. Formula I have a pH 3,5 while formula II and III having a ph $5(\mathrm{p}<0,05)$. The 
greater spreadibility given by formula III $(\mathrm{p}<0,05)$ and the longest time of adhesivity given by formula II $(p<0,05)$. The best activity of wound healing given by formula I $(p>0,05)$. Based on the result show that type of gelling agent can influence the physical properties and activity in the treating burns. Type of gelling agent that show the best physical properties is CMC Na.

Keywords: pericarp of mangosteen, gel, gelling agent, physical characteristic gel, wound healing

\section{PENDAHULUAN}

Tanaman yang mengandung antioksidan banyak dipakai dalam pengobatan tradisional. Salah satu tanaman yang mengandung antioksidan adalah kulit buah manggis (Weecharangsan et al., 2006). Penelitian mengenai aktivitas antioksidan kulit buah manggis menyebutkan bahwa kulit manggis dapat mempercepat proses pemulihan sel dengan mempercepat proses proliferasi fibroblas (Asri, 2012).

Penggunaan kulit buah manggis untuk menyembuhkan luka bakar dapat dipermudah dengan membuat dalam bentuk sediaan gel. Sediaan gel mempunyai beberapa keuntungan diantaranya tidak lengket, mudah dioleskan, mudah dicuci dan tidak meninggalkan lapisan berminyak pada kulit sehingga mengurangi resiko timbulnya peradangan lebih lanjut akibat menumpuknya minyak pada pori-pori (Lieberman et al., 1998).

Formulasi gel membutuhkan senyawa gelling agent sebagai bahan pembentuk gel. Gelling agent bermacam-macam jenisnya, diantaranya adalah $\mathrm{CMC} \mathrm{Na}$, karbopol dan tragakan. CMC $\mathrm{Na}$ merupakan basis gel golongan polimer semi sintetik, karbopol termasuk basis golongan sintetik sedangkan tragakan termasuk basis gel golongan gom alam (Swarbrick dan Boylan, 1989). Perbedaan sifat antara ketiga gelling agents dapat menimbulkan perbedaan difusi obat sehingga mempengaruhi efek penyembuhan luka bakar. Penelitian ini bertujuan untuk mengetahui secara ilmiah pengaruh jenis gelling agent dalam sediaan gel ekstrak etanol kulit buah manggis terhadap sifat fisik dan aktivitas luka bakar.

\section{METODE PENELITIAN}

\section{Bahan Penelitian}

Bahan yang digunakan dalam penelitian ini $\mathrm{CMC} \mathrm{Na}$, carbopol, tragakan, gliserin, metal paraben, propilenglikol, masing-masing kualitas farmasetis dan diperoleh dari PT Brataco, aquadest, kloroform, etil asetat, metanol, $\mathrm{HCl}$ pekat, serbuk Mg, Eter, cotton bud, kertas millimeter blok, tikus jantan galur wistar umur 2 bulan, pakan dan minum tikus.

\section{Jalannya Penelitian}

\section{Pembuatan simplisia}

Kulit manggis dipisahkan dari buahnya kemudian dirajang dan dibersihkan dengan air mengalir. Setelah itu diangin-anginkan dibawah sinar matahari selama 1 hari dan dimasukkan dalam oven $50^{\circ} \mathrm{C}$ sampai kering. Setelah kering kulit manggis diblender dan diayak dengan ayakan no 65 mesh.

\section{Pembuatan ekstrak etanol kulit buah manggis}

Ekstrak etanol kulit buah manggis diperoleh dengan menggunakan metode maserasi dengan pelarut etanol $70 \%$ dengan perbandingan 4:1. Simplisia kemudian direndam dengan etanol $70 \%$ dan diaduk dengan maserator selama 3 jam dan didiamkan 24 jam. Filtrat disaring dan ampas selanjutnya diremaserasi sebanyak 2 kali. Filtrat hasil maserasi dijadikan satu kemudian etanol dihilangkan dengan rotary evaporator dan dipekatkan dalam waterbath.

\section{Penetapan kadar air ekstrak}

Kadar air ekstrak etanol kulit buah manggis ditetapkan dengan alat Halogen Moisture Analyzer. Ekstrak yang diuji 
sebanyak 1 gram dengan suhu $105^{\circ} \mathrm{C}$ selama 15 menit.

\section{Uji reaksi warna Xanthone}

Identifikasi xanthone dalam ekstrak dilakukan dengan memasukkan sejumlah ekstrak kedalam tabung reaksi yang kemudian ditambah serbuk $\mathrm{Mg}$ dan $\mathrm{HCl}$ pekat dan kemudian dikocok hingga serbuk Mg larut. Hasil positif ditunjukan dengan terbentuknya warna merah, kuning atau jingga (Harborne, 1987).

\section{Uji kromatografi lapis tipis \\ flavonoid}

Identifikasi flavonoid dalam ekstrak dilakukan dengan metode KLT dilakukan dengan menggunakan fase diam silica gel GF254 dan fase gerak etil asetat:methanol:air (100:13,5:1). Deteksi bercak dilakukan dengan menggunakan sinar UV $\lambda 254 \mathrm{~nm}$ dan $\lambda 366$ $\mathrm{nm}$.

\section{Pembuatan sediaan gel}

Gel ekstrak etanol kulit buah manggis dibuat berdasarkan formula yang disajikan pada Tabel I. Pembuatan gel diawali dengan mengembangkan gelling agent dalam $10 \mathrm{ml}$ air pada suhu $70^{\circ} \mathrm{C}$, ditambahkan ekstrak disebut campuran 1.

Metil paraben dilarutkan dalam sedikit air kemudian ditambahkan campuran gliserin dan propilenglikol yang kemudian disebut campuran 2. Kedua campuran dijadikan satu, setealh itu diaduk dan ditambahkan air ad 20 gram kemudian diaduk homogen.

\section{Uji sifat fisik gel}

a. Pengujian organoleptik dan homogenitas

Uji organoleptik dilakukan dengan pengamatan secara langsung warna dan bau gel. Pengujian homogenitas dilakukan dengan mengoleskan gel pada sekeping kaca.

\section{b. Pengujian $\mathrm{pH}$}

Pengujian $\mathrm{pH}$ dilakukan dengan menggunakan kertas $\mathrm{pH}$ universal yang dicelupkan ke dalam sampel gel yang telah diencerkan. Perubahan warna yang terjadi dicocokkan dengan standar $\mathrm{pH}$ universal.

\section{c. Pengujian daya sebar}

Sebanyak 0,5 gram gel diletakan dalam kaca bulat, kaca lainnya diletakan di atasnya dan dibiarkan selama 1 menit. Setelah itu, ditambahkan 150 gram beban didiamkan 1 menit dan diukur diameter konstan (Astuti et al., 2010).

\section{d. Pengujian daya lekat}

Sampel 0,25 gram diletakkan diantara 2 gelas objek pada alat uji daya lekat, kemudian ditekan beban $1 \mathrm{~kg}$ selama 5 menit, beban diangkat dan diberi beban 80 gram pada alat dan dicatat waktu peleasan gel (Miranti, 2009).

\section{e. Pengujian konsistensi}

Pengujian konsistensi dilakukan dengan menggunakan centrifugal test diaman sampel gel disentrifugasi pada kecepatan 3800 rpm selama 5 jam kemudian diamati perubahan fisiknya (Djajadisastra et al, 2009).

\section{Uji luka bakar}

Pengujian efek menyembuhkan luka bakar dilakukan pada punggung tikus yang dicukur bulunya kemudian dianastesi dengan eter dan diinduksi dengan lempeng panas berupa stainless steel ukuran $2 \mathrm{X} 2 \mathrm{~cm}$ suhu $80^{\circ} \mathrm{C}$ selama 10 detik. Luka yang terjadi diukur, setelah itu dioles gel $350 \mathrm{mg}$.

\section{Pengukuran luas area luka bakar}

Pengukuran luas area luka dilakukan setiap minggu selama 1 bulan. Metode pengukuran luas area luka bakar dilakukan dengan menggunakan kertas millimeter blok. Kaca arloji ditempatkan di area luka, dengan spidol area luka digambar dalam kaca arloji, kemudian luka yang telah digambar di kaca arloji ditentukan luasnya dengan menggunakan kertas millimeter blok.

\section{Kelompok hewan uji}

Kelompok hewan uji pada uji luka bakar gel disajikan pada Tabel II.

\section{Analisis data}

Data sifat fisik gel dan aktivitas pengobatan luka bakar yang dihitung dengan rumus: 
Persentase $=$ Kesembuhan $=\frac{A_{0}-A_{x}}{A_{0}} \times 100 \%$

Dimana $\mathrm{A}_{0}=$ luas area luka mula-mula (minggu ke-0) dan $A_{x}=$ luas area luka pada minggu ke-x. Hasil perhitungan lalu dianalisis statistika dengan menggunakan Kruskal Wallis dilanjutkan dan dengan uji Mann Whitney.

\section{HASIL DAN PEMBAHASAN}

Proses ekstraksi kulit manggis menghasilkan rendemen sebesar 27,13\%. Hasil penetapan kadar air didapatkan rata-rata kadar air 7,58\%. Nilai tersebut $<10$ sudah sesuai dengan syarat nilai kadar air ekstrak (Anonim, 2010). Hasil identifikasi xanthone menunjukkan bahwa ekstrak etanol kulit buah manggis mengandung xanthone yang ditujukkan dengan warna menjadi jingga. Prinsip uji reaksi warna xanthone adalah proses reduksi dimana penambahan serbuk $\mathrm{Mg}$ dan $\mathrm{HCl}$ pekat akan mereduksi xanthone dalam ekstrak. Selain identifikasi xanthone juga dilakukan identifikasi flavonoid. Jalur biosintesis xanthone sangat erat kaitannya dengan jalur biosintesis flavonoid, untuk itu uji KLT flavonoid dapat mengarah pada adanya xanthone.

Hasil uji KLT menunjukan nilai Rf antara sampel dan pembanding adalah sama yaitu 0,725 . Hal ini berarti dalam ekstrak etanol kulit buah manggis terdapat senyawa flavonoid. Komponen lain selain gelling agent dalam formula gel yaitu propilen glikol dan gliserin yang berfungsi sebagai humektan dan menjaga stabilitas sediaan, metil paraben sebagai pengawet dan aquades sebagai pelarut.

Gel yang diperoleh kemudian diuji organoleptik dan pH-nya, dan yang hasilnya disajikan pada Tabel III. Hasil uji homogenitas menunjukan bahwa sediaan gel homogen secara fisik dan tidak terjadi fenomena sineresis yang menandakan bahwa bahan-bahan dalam gel terlarut dan bercampur sempurna. Hasil uji $\mathrm{pH}$ menunjukkan bahwa $\mathrm{pH}$ formula I tidak memenuhi kriteria $\mathrm{pH}$ sediaan topikal yaitu rentang $\mathrm{pH}$ 4,5-6,5 (Djajadisastra et al., 2009), sedangkan formula II dan III memenuhi persyaratan. Adanya penambahan ekstrak pada formula I dapat meningkatkan nilai $\mathrm{pH}$ sebab ekstrak kulit manggis memiliki pH 5,36 (Sothornvit, 2012). Pada formula II adanya penambahan ekstrak dapat menurunkan nilai $\mathrm{pH}$ sebab gelling agent CMC Na pada formula II memilki nilai pH 6,5-8,5 (Anonim, 1995) lebih tinggi dari $\mathrm{pH}$ kulit manggis sehingga $\mathrm{pH}$ pada formula II akan turun. Sedangkan pada formula III nilai $\mathrm{pH}$ dengan adanya penambahan ekstrak tetap sama sebab $\mathrm{pH}$ tragakan berkisar 5-6 tidak berbeda jauh dengan $\mathrm{pH}$ kulit manggis. Jika dibandingkan antara ketiga formula maka formula I memiliki $\mathrm{pH}$ yang tidak sesuai dengan $\mathrm{pH}$ sediaan topikal. Hal ini dipengaruhi gelling agent karbopol pad formula I yang bersifat asam. Hasil analisis statistika menunjukan nilai signifikansi $<0,05$ yang berarti bahwa nilai $\mathrm{pH}$ antara formula memilki perbedaan yang signifikan.

Tabel I. Formula gel ekstrak etanol kulit buah manggis dengan gelling agent: carbopol (FI), CMC Na (FII) dan tragakan (FIII).

\begin{tabular}{cccc}
\hline Komponen & F I & F II & F III \\
\hline Ekstrak Etanol Kulit Buah Manggis & $2 \mathrm{~g}$ & $2 \mathrm{~g}$ & $2 \mathrm{~g}$ \\
Karbopol & $1 \mathrm{~g}$ & - & - \\
CMC Na & - & $1 \mathrm{~g}$ & - \\
Tragakan & - & - & $1 \mathrm{~g}$ \\
Gliserin & $2 \mathrm{~g}$ & $2 \mathrm{~g}$ & $2 \mathrm{~g}$ \\
Propilenglikol & $1 \mathrm{~g}$ & $1 \mathrm{~g}$ & $1 \mathrm{~g}$ \\
Metil Paraben & $0,03 \mathrm{~g}$ & $0,03 \mathrm{~g}$ & $0,03 \mathrm{~g}$ \\
Air ad & $20 \mathrm{~g}$ & $20 \mathrm{~g}$ & $20 \mathrm{~g}$ \\
\hline
\end{tabular}


Tabel II. Kelompok perlakuan hewan uji luka bakar

\begin{tabular}{ccc}
\hline No & Kelompok & Komponen Dalam Mengobati Luka Bakar \\
\hline 1 & K(-) & Tidak diberi pengobatan luka bakar \\
2 & K(+) & Obat komersil bioplacenton \\
3 & KK & Komponen dalam formula tanpa gelling agent \\
4 & K1a & I \\
& & Formula I tanpa ekstrak \\
5 & K1b & Formula \\
6 & K2a & II \\
7 & K2b & Formula II tanpa ekstrak \\
8 & K3a & III \\
9 & K3b & Formula III tanpa ekstrak \\
\hline
\end{tabular}

Tabel III. Hasil pengujian organoleptis dan pH gel ekstrak etanol kulit buah manggis

\begin{tabular}{|c|c|c|c|}
\hline \multirow[b]{2}{*}{ Formula Gel } & \multicolumn{2}{|c|}{ Uji Organoleptis } & \multirow{2}{*}{$\begin{array}{c}\mathrm{pH} \\
\mathrm{X} \pm \mathrm{SD}\end{array}$} \\
\hline & Warna & Bau & \\
\hline Formula I & Coklat & $\begin{array}{c}\text { Khas kulit } \\
\text { manggis }\end{array}$ & $3,5 \pm 0$ \\
\hline Formula I tanpa ekstrak & Putih bening & Khas gliserin & $2,5 \pm 0$ \\
\hline Formula II & Coklat & $\begin{array}{l}\text { Khas kulit } \\
\text { manggis }\end{array}$ & $5 \pm 0$ \\
\hline Formula II tanpa ekstrak & Putih kekuningan & Khas CMC Na & $6 \pm 0$ \\
\hline Formula III & Coklat pekat & $\begin{array}{l}\text { Khas kulit } \\
\text { manggis }\end{array}$ & $5 \pm 0$ \\
\hline Formula III tanpa ekstrak & Putih tulang & Khas tragakan & $5 \pm 0$ \\
\hline
\end{tabular}

Uji daya sebar bertujuan untuk mengetahui penyebaran gel diatas kulit, semakin besar luass penyebaran maka semakin mudah diaplikasikan pada kulit sehingga absorbs pada kulit semakin maksimal. Hasil uji daya sebar dapat dilihat pada Gambar 1.

Luas area sebar gel formula I dengan gelling agent karbopol lebih rendah dibandingkan dengan formula I tanpa ekstrak. Hal ini dikarenakan adanya penambahan ekstrak pada formula I dapat meningkatkan viskositas gel (lebih kental) sehingga dapat menurunkan daya penyebaran gel. Pada formula II gelling agent $\mathrm{CMC} \mathrm{Na}$ dengan adanya penambahan ekstrak tidak menurunkan daya penyebaran gel. Hal ini dikarenakan saat CMC Na dimasukkan ke dalam air, $\mathrm{Na}^{+}$lepas dan diganti dengan ion $\mathrm{H}^{+}$dan membentuk $\mathrm{CMCH}$ yang akan meningkatkan viskositas (Bochek et al., 2002). Selain itu besarnya gaya kohesi yang dimiliki oleh gelling agent CMC Na membuat interaksi antar molekul sejenis lebih besar dan menyebabkan sediaan cenderung mengumpul dan sulit menyebar (Erawati et al., 2013). Oleh sebab itu dengan adanya penambahan ekstrak justru dapat meregangkan interaksi antar molekul CMC Na sehingga menurunkan daya sebar. Pada formula III gelling agent tragakan dengan adanya penambahan ekstrak dapat menaikkan viskositas (lebih kental). Sehingga daya sebar formula III akan lebih kecil dari pada daya sebar formula III tanpa esktrak. 
Daya sebar formula II paling kecil diantara formula lainnya yang disebabkan konsistensi yang paling kecil. Hasil uji statistika diperoleh signifikansi $0,010(<0,05)$. Hal ini menunjukan luas daya sebar antara formula memiliki perbedaan yang signifikan atau berbeda bermakna. Uji daya lekat bertujuan untuk mengetahui waktu yang dibutuhkan gel tersebut untuk menempel pada kulit dan mengetahui pengaruh jenis gelling agent terhadap daya lekatnya. Hasil uji daya lekat gel terdapat pada Gambar 2. Waktu daya lekat formula I dengan gelling agent karbopol lebih lama dari pada waktu daya lekat formula I tanpa ekstrak. Hal ini dikarenakan adanya penambahan ekstrak dapat meningkatkan viskositas (lebih kental) sehingga dapat meningkatkan waktu perlekatan gel. Pada formula II dengan gelling agent CMC $\mathrm{Na}$ waktu daya lekat lebih pendek dari pada formula II tanpa ekstrak.

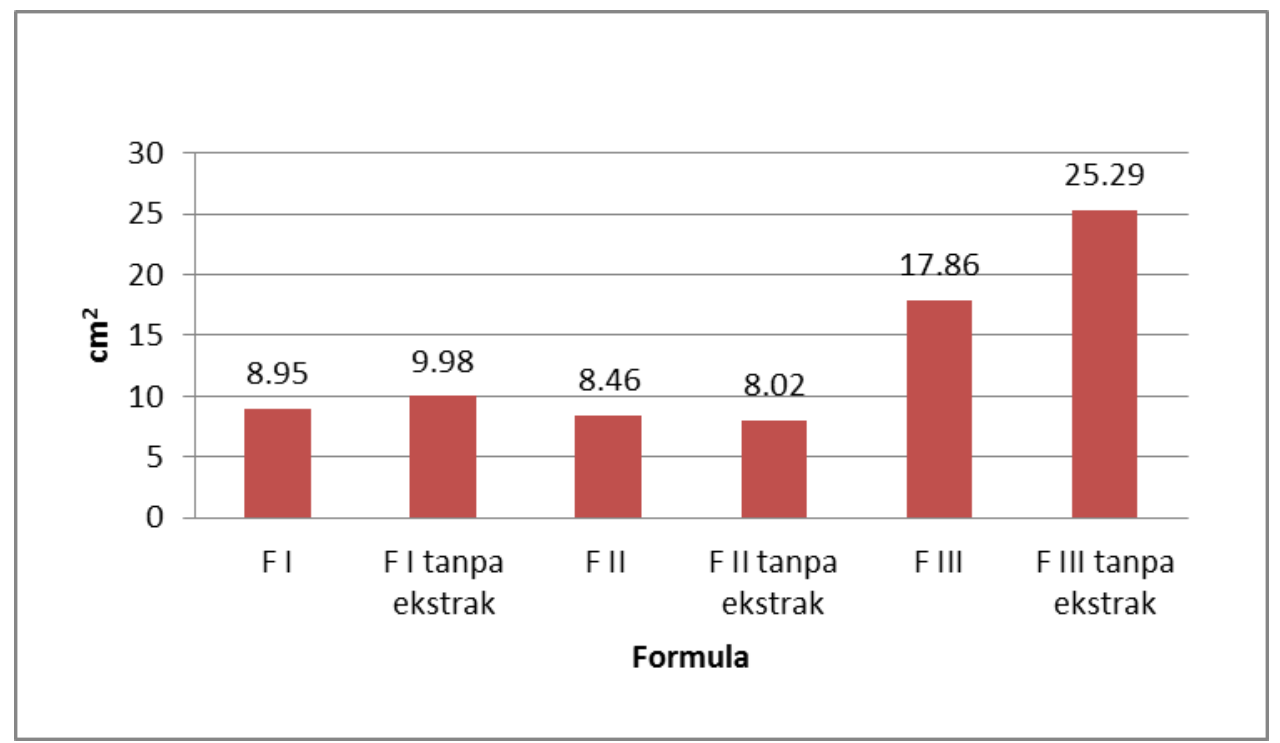

Gambar 1. Grafik Luas Area Penyaberan Gel Ekstrak Etanol Kulit Buah Manggis.

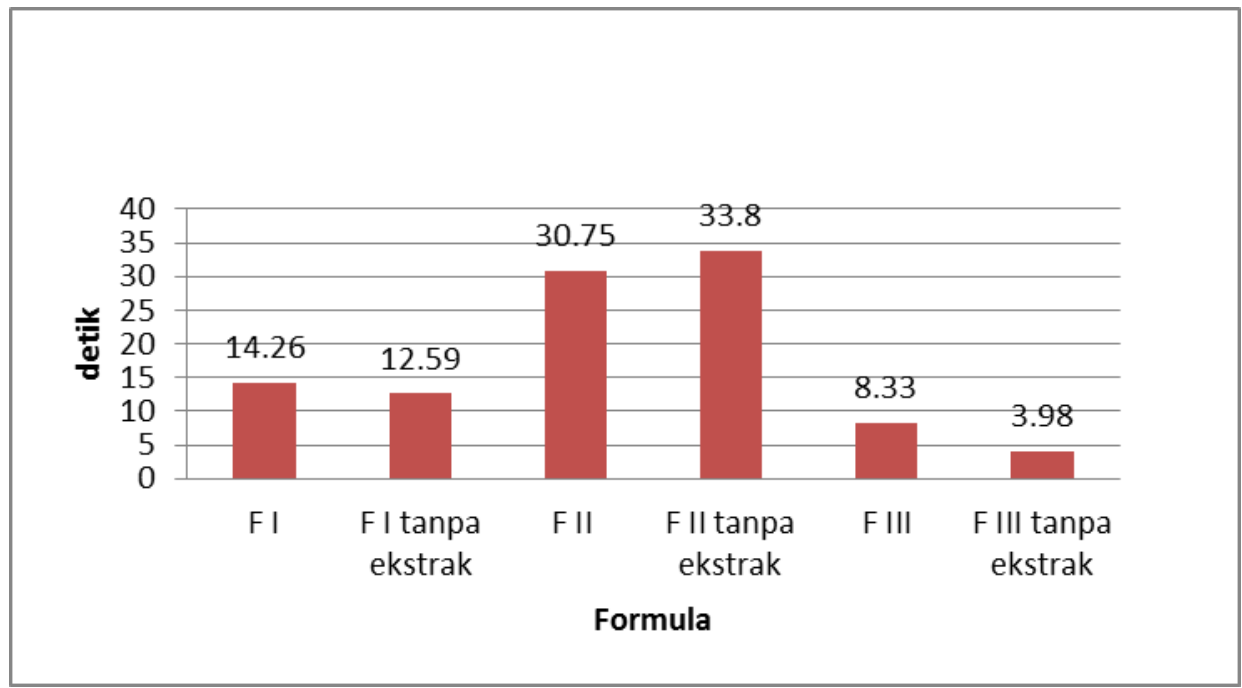

Gambar 2. Grafik Rata-Rata Daya Lekat Gel Ekstrak Etanol Kulit Buah Manggis 
Adanya penambahan ekstrak tidak meningkatkan waktu perlekatan. Hal ini disebabkan oleh sifat gelling agent pada formula II yaitu CMC Na yang memberikan viskositas yang besar sehingga gel yang menempel di kulit menjadi lebih lama. CMC Na saat dimasukkan ke dalam air, $\mathrm{Na}^{+}$lepas dan diganti dengan ion $\mathrm{H}^{+}$dan membentuk $\mathrm{CMCH}$ yang akan meningkatkan viskositas (Bochek et al., 2002). Selain itu adanya penambahan ekstrak dapat menurunkan gaya kohesi sehingga ikatan antar molekul CMC Na menjadi berkurang (Erawati et al., 2013). formula III gelling agent tragakan seperti halnya pada formula I, dengan adanya penambahan ekstrak dapat meningkatkan kekentalan dari gel formula III sehingga berakibat waktu perlekatan formula III akan lebih pendek dibandingkan waktu lekat formula III tanpa ekstrak. Jika dibandingkan antara ketiga formula maka waktu lekat formula III dengan gelling agent tragakan memilki waktu lekat yang paling cepat Sedangkan pada formula II memiliki waktu lekat yang lebih lama. Hal ini disebabkan konsistensi formula II yang paling kecil. Hasil uji statitika diperoleh signifikansi $0,000 \quad(<0,05)$. Hal ini menunjukan waktu daya lekat antara formula memiliki perbedaan yang signifikan atau berbeda bermakna.Hasil uji konsistensi menunjukan sediaan gel pada ketiga formula tidak terjadi fase pemisahan dan dengan begitu dapat dikatakan bahwa sediaan gel stabil dalam proses penyimpanan

Dalam menguji efek menyembuhkan luka bakar gel digunakan Sembilan kelompok perlakuan dengan masing-masing terdiri dari empat ekor tikus yaitu: K (-) adalah kelompok yang tidak diberikan pengobatan luka bakar, $\mathrm{K}$ (+) adalah kelompok yang diberikan obat komersil bioplacenton, KK adalah kelompok yang diberikan komponen dalam formula tanpa gelling agent, K1a adalah kelompok yang diberikan formula I, K1b adalah kelompok yang diberikan formula I tanpa ekstrak, K2a adalah kelompok formula II, K2b adalah kelompok formula II tanpa ekstrak, K3a adalah kelompok formula III dana K3b adalah kelompok formula III tanpa ekstrak. Hasil uji luka bakar dapat dilihat pada Gambar 3.
Hasil penelitian menunjukan bahwa ketiga formula gel memiliki efek megobati luka bakar dengan persentase kesembuhan lebih besar dari $\mathrm{K}(-)$ dan lebih baik dari $\mathrm{K}(+)$. Dari ketiga formula jika dibandingkan maka kelompok K1a atau kelompok dengan formula I dengan gelling agent karbopol memberikan efek menyembuhkan luka bakar paling baik dari pada formula II dengan gelling agent $\mathrm{CMCNa}$ (kelompok K2a) dan formula III dengan gelling agent tragakan (kelompok K3a). Hal ini berkaitan dengan sifat fisik gel yang mempengaruhi pelepasan zat aktif dari ekstrak kulit manggis yang berkhasiat menyembuhkan luka bakar.

Pada kelompok K2a (formula II) memiliki efek menyembuhkan luka bakar yang paling rendah disebabkan oleh viskositas sediaan yang tinggi (lebih kental) akibat gaya kohesi gelling agent yang tinggi yaitu $\mathrm{CMC} \mathrm{Na}$ sehingga menyebabkan daya sebar yang pendek walaupun daya lekat paling lama diantara formula I dan formula II namun pelepasan zat aktif pada formula II tidak maksimal karena tertahan oleh gelling agent $\mathrm{CMC} \mathrm{Na}$. Sementara itu untuk kelompok K3a (formula III) efek menyembuhkan luka bakar tidak sebaik pada kelompok K1a (formula I). Walaupun daya sebar pada formula III paling besar namun karena viskositas yang terlalu encer mengakibatkan daya lekat yang pendek sehingga zat aktif yang terabsorbsi di kulit jumlahnya sedikit.

Dari pengamatan luka bakar yang diberikan pada punggung tikus menunjukkan adanya perubahan yang berarti, dimana luka tertutupi dahulu pada bagian atas oleh darah yang membeku yang membentuk lapisan kerak atau scab. Lapisan kerak atau scab ini bertujuan untuk mencegah terjadinya oksidasi pada luka sehingga mencegah mikroorganisme atau kuman bakteri yang ada disekitar luka berkembang. Hal ini diperkuat dengan penelitian Sakagami et al. (2005) dimana alfa-mangostin memiliki khasiat sebagai antibakteri dengan aktivitas yang sinergisme dengan beberapa antibiotika (gentamisin dan vancomisin). 


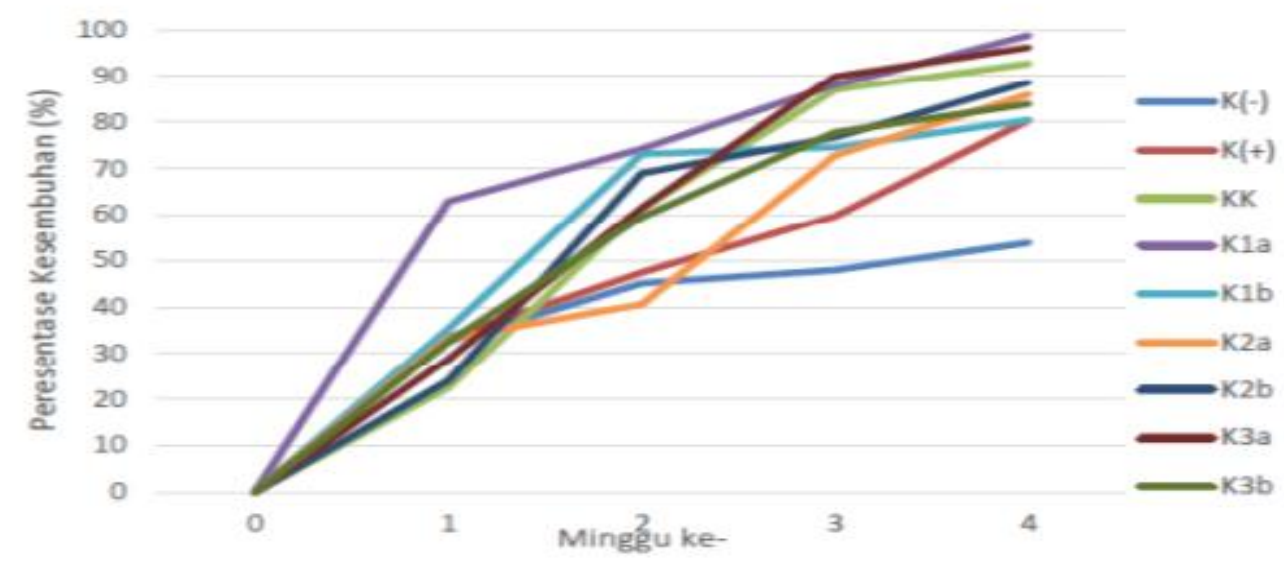

Gambar 3. Grafik rata-rata peresentase kesembuhan luka bakar (\%) dengan interval pengukuran setiap minggu.

Senyawa gamma mangostin dalam esktrak kulit manggis memiliki khasiat sebagai anti-inflamasi dengan penghambatan COX-2 sehingga mempercepat proses penyembuhan luka pada fase inflamasi (Nakatani et al., 2004). Selain pada fase inflamasi, ekstrak kulit manggis berperan dalam menyembuhkan luka bakar pada fase proliferasi dimana ekstrak kulit manggis dapat meningkatkan proses epitelisasi dan mempercepat proliferasi fibroblas (Yuliadi, 2013 :Asri, 2012).

Berdasarkan uji Kruskal-Wallis diperoleh nilai signifikansi $\mathrm{p}>0,05$, hal ini menunjukkan bahwa secara statistika formula I, II dan III memiliki efek menyembuhkan luka bakar yang sama. Perbedaan jenis gelling agent tidak berpengaruh secara signifikan pada aktivitas mengobati luka bakar ( $\mathrm{p}>0,05)$.

\section{KESIMPULAN}

Jenis gelling agent dapat mempengaruhi sifat fisik gel dan aktivitas sebagai obat luka bakar $(p>0,05)$. Jenis gelling agent yang memberikan sifat fisik gel yang baik adalah gelling agent $\mathrm{CMC} \mathrm{Na}$.

\section{UCAPAN TERIMAKASIH}

Terimakasih kepada DIKTI yang telah memberikan bantuan dana melalui dana mekanisme Hibah PKM tahun 2014 sehingga terlaksananya penelitian ini.

\section{DAFTAR PUSTAKA}

Anonim, 1985, Formularium Kosmetika Indonesia, Departemen Kesehatan RI, Jakarta.

Anonim, 1995, Farmakope Indonesia, Edisi IV, Departemen Kesehatan RI, Jakarta.

Anonim, 2010, Suplemen I Farmakope Herbal Indonesia, Departemen Kesehatan Republik Indonesia, Jakarta.

Asri, D. P., 2012, Efektivitas Ekstrak Kulit Manggis (Garcinia mangostana L.) Terhadap Percepatan Proliferasi Fibroblas pada Proses Penyembuhan Luka Traumatik Akut Mukosa Mulut Tikus Wistar, Skripsi, Fakultas Kedokteran Gigi Universitas Airlangga, Surabaya.

Astuti I. Y., D. Hartanti, dan A. Aminiati, 2010, Peningkatan Aktivitas Antijamur Candidia albicans Salep Minyak Atsiri Daun Sirih (Piper bettle LINN.) melalui Pembentukan Kompleks Inklusi dengan $\beta$-siklodekstrin, Majalah Obat Tradisional,15: 94 - 99 .

Bochek, A. M., Yusupova, L. D., Zabivalova, N.M., Petropavlovskii, G. A., 2002, 
Rheological Properties of Aqueous $\mathrm{H}-$ Carboxymethyl Cellulose Solutions with Various Additives, Russian Journal of Applied Chemistry, 75: 4-7.

Djajadisastra, J., Mun'im, A., Desi, N. P., 2009, Formulasi Gel Topikal Dari Ekstrak Nerii folium Dalam Sediaan Antijerawat, Jurnal Farmasi Indonesia 4 (4) : 210-216.

Erawati, T., Rosita, N., Hendroprasetyo, W., Juwita, D. R., 2013, Pengaruh Jenis Basis Gel dan Penambahan $\mathrm{NaCl}(0,5 \%$ b/b) terhadap Intensitas Echo Gelombang Ultrasonik Sediaan Gel Untuk Pemeriksaan USG (Acoustic Coupling Agent), Laporan Penelitian, Fakultas Farmasi Universitas Airlangga dan Teknik Perkapalan Institusi Teknologi Sepuluh November, Surabaya.

Harborne, J.B., 1987, Metode Fitokimia Penuntun Cara Modern Menganalisis Tumbuhan, Edisi II, diterjemahkan oleh Kosasih Padmawinata dan Iwang Soedira, 5, 69-76, ITB Press, Bandung.

Lieberman, A. H., Rieger, M.M., dan Banker S.G., 1998, Pharmaceutical Dosage Forms: Disperse System, $2^{\text {nd }}$ Ed., Revised and Expanded, 3, 265-267, 272273, Marcell Dekker, Inc., New York.

Miranti, L., 2009, Pengaruh Konsentrasi Minyak Atsiri Kencur (Kaemferia galangal) Dengan Basis Salep Larut Air terhadap Sifat Fisik Salep dan Daya Hambat Bakteri Staphylococcus aureus Secara In Vitro, Skripsi, Fakultas Farmasi Univeritas Muhammadiyah Surakrta, Surakarta.
Nakatani, K., Yamakuni., Kondo, N., Arakawa, T., Oosawa, K., Shimura, S., Inoue, H., dan Ohizumi, Y., 2004, GammaMangostin Inhibits Ikappa-B Kinase Activity and Decrease Lipopolysaccharide-Induced Cyclooxygenase-2 Gene Expression in C6 Rat Hlioma Cells, Mol. Pharmacol., 24 Juni 2004.

Sakagami Y., Linuma, M., Piyasena, K. G., Dharmaratne, H. R., 2005, Antibacterial Acitivity of Alpha-mangosti Againts Vancomycin Resistant Enterococci (VRE) and Synergism with Antibiotics, Phytomedicine, 12(3):203-208.

Sothornvit, R., 2012, Drying Process And Mangosteen Rind Powder Product, ActaHort (ISHS), 928:233-241.

Swarbrick, J. dan J. Boylan, 1989, Gel dan Jellies, in Encyclopedia of Pharmaceutical Technology, Vol. 6, Marcel Dekker Inc., New York.

Weecharangsan W., Opanasopit P., Sukma M., Ngawhirunpat T.,Sotanaphun U., Siripong P., 2006, Antioxidative and Neuroprotective Acitivites of Extraxts From the Fruit Hull of Mangosteen (Garcinia mangostana Linn.), Medical Principles and Practice, 15(4):281-287.

Yuliadi, N. 2013, Efek Aplikasi Gel Ekstrak Kulit Manggis (Garcinia mangostana L.) Terhadap Re-Epitelisasi Pada Proses PenyembuhanLuka Gingiva (Kajian Pada Rattus norvegicus), Skripsi, Fakultas Kedokteran Gigi Universitas Gajah Mada, Yogyakarta. 
